\title{
Manganese and Parkinson's Disease: A Critical Review and New Findings
}

\author{
Manganês e Doença de Parkinson: \\ Uma revisão crítica e novas descobertas
}

Tomás R. Guilarte ${ }^{1}$

${ }^{1}$ Neurotoxicology and Molecular Imaging Laboratory, Department of Environmental Health Sciences, Johns Hopkins Bloomberg School of Public Health, Baltimore, Maryland, USA

60 Haven Ave., B1-108. 10032 New York NY USA. trguilarte@columbia.edu
Abstract The goal of this review was to examine whether chronic Mn exposure produces dopamine neuron degeneration and PD or whether it has a distinct neuropathology and clinical presentation. I reviewed available clinical, neuroimaging, and neuropathological studies in humans and nonhuman primates exposed to $\mathrm{Mn}$ or other human conditions that result in elevated brain Mn concentrations. Human and nonhuman primate literature was examined to compare clinical, neuroimaging, and neuropathological changes associated with Mn-induced parkinsonism. Clinical, neuroimaging, and neuropathological evidence was used to examine whether $M n$-induced parkinsonism involves degeneration of the nigrostriatal dopaminergic system as is the case in PD. The overwhelming evidence shows that $M n$-induced parkinsonism does not involve degeneration of midbrain dopamine neurons and that $l$ dopa is not an effective therapy. New evidence is presented on a putative mechanism by which $\mathrm{Mn}$ may produce movement abnormalities. Confirmation of this hypothesis in humans is essential to make rational decisions about treatment, devise effective therapeutic strategies, and set regulatory guidelines.

Key words Basal ganglia, Dopamine, Humans, Manganese, Movement disorder, Neuroimaging, Neurotoxicity, Nonhuman primates, Parkinson's disease, Striatum
Resumo O objetivo desta revisão foi examinar se a exposição crônica ao $\mathrm{Mn}$ produz degeneração do neurônio pela dopamina e DP ou se é apenas uma apresentação neuropatológica e clínica diferente. Foram revisados estudos clínicos, de neuroimagens e neuropatológicos disponíveis sobre humanos e primatas expostos ao Mn ou outras condições humanas que resultam em concentrações elevadas de Mn no cérebro. Foi examinada a literatura sobre humanos e primatas e comparadas as mudanças clínicas de neuroimagem e neuropatológicas associadas com o "parkinsonimo" induzido por Mn, envolvendo a degeneração do sistema dopaminérgico nigro-estriatal como no caso da DP. as evidências decisivas mostram que o "parkinsonismo" induzido pelo $\mathrm{Mn}$ não envolve a degeneração dos neurônios de dopamina do mesencéfalo e que o dopa-1 não é uma terapia eficaz. Novas evidências estão presentes em um mecanismo putativo pelo qual o Mn pode produzir anormalidades de movimento. A confirmação desta hipótese em humanos é essencial para tomar decisões adequadas sobre o tratamento, planejar estratégias terapêuticas eficazes e estabelecer guias regulatórios.

Palavras-chave Gânglio basal, Dopamina, Humanos, Manganês, Desordens de movimento, Neuroimagem, Neurotoxicidade, Primatas, Doença de Parkinson, Estriatal 
Idiopathic Parkinson's disease (PD) is a progressive neurodegenerative disorder with a slow onset, and compared with the familial forms of the disease, it is associated with advanced age ( $>55$ years of age). The four cardinal signs of idiopathic PD are tremor at rest, bradykinesia (hypokinesia and akinesia), rigidity, and postural instability (Jankovic 2008; Lees et al. 2009; Tolosa et al. 2006). The diagnosis of idiopathic PD is typically based on the presence of two or more of the four cardinal signs and a response to l-dopa therapy. Unilateral tremor of the hand at rest with a frequency of $4-6 \mathrm{~Hz}$ is the earliest and most easily recognized symptom of PD. Autopsy-based studies have shown that the percentage of patients with confirmed PD diagnosis who exhibited resting tremor ranges from 76-100\% (Hughes et al. 1993; Louis et al. 1997; Rajput et al. 1991).

Bradykinesia is defined by slowness of movements or difficulty in initiating and executing movement, and it is one of the essential signs used to diagnose idiopathic PD (Lees et al. 2009). Bradykinesia appears to correlate with the degree of dopamine deficiency in the caudate and putamen (striatum) (Vingerhoets et al. 1997). Rigidity is characterized by increased resistance of the limbs and is the result of the muscles becoming tensed and contracted so that the person feels stiff and weak. Postural instability is the loss of postural reflexes, and this occurs in the late stages of the disease. Postural instability causes patients to develop a forward or backward lean that causes them to fall. As the disease progresses, walking is affected, and patients walk in quick, small steps like they are hurrying forward in order to maintain balance.

Although the clinical diagnosis of PD is based on a combination of the four cardinal motor signs, other parkinsonian disorders also express many of these signs (Tolosa et al. 2006), and a definite diagnosis of PD requires neuropathological confirmation (Gelb et al. 1999). It has been estimated that $>10 \%$ of PD cases can be diagnosed incorrectly by movement disorder specialists when clinical signs are the only basis for diagnosis (Hughes et al. 2002). Consistent with the known deficiency of dopamine in the striatum, the clinical symptoms of PD are significantly alleviated with 1-dopa therapy, the precursor substrate for the synthesis of dopamine, the chemical that is decreased in PD (Savitt et al. 2006). This is important information when one examines the hypothesis that manganese $(\mathrm{Mn})$-induced parkinsonism involves nigrostriatal dopamine neuron degeneration.

Molecular imaging is a useful strategy for the diagnosis of PD and has provided extensive evidence that PD patients exhibit decreased levels of presynaptic dopamine neuron terminal markers in the striatum (Felicio et al. 2009). This is consistent with the loss of dopamine terminals as a result of degeneration of neuronal cell bodies in the substantia nigra pars compacta $(\mathrm{SNpc})$ (Figure 1). Single photon emission computed tomography (SPECT) and positron emission tomography (PET) studies have shown that PD patients exhibit decreased levels of dopamine transporters (DATs) and vesicular monoamine transporter type 2 (VMAT2) and reduced activity of dopa decarboxylase as measured by the conversion of 1-dopa to dopamine in the striatum using [18F]-fluorodopa PET (Felicio et al. 2009). Postsynaptic D2dopamine receptors (D2Rs) either are not affected or are increased in the striatum of untreated PD patients (Antonini et al. 1994; Brooks et al. 1992; Rinne et al. 1990). Similar changes in these markers have been documented in a nonhuman primate model of PD (Chen et al. 2008).

A major discovery in understanding the molecular basis of PD came about when a deficit in the concentration of the neurotransmitter dopamine was discovered in the striatum of brain samples from PD patients (Ehringer and Hornykiewicz 1960; Hornykiewicz 2006). Scientists now know that a marked loss of dopamine-containing neurons in the SNpc results in decreased dopamine levels in the caudate and putamen (Savitt et al. 2006). A hallmark neuropathological feature of SNpc dopamine neurons in PD is proteinacious intraneuronal aggregations called Lewy bodies that seem to be associated with dopamine neuron degeneration (Dauer and Przedborski 2003; Wakabayashi et al. 2007).

In summary, idiopathic PD patients exhibit resting tremor, bradykinesia, rigidity, and postural instability that is the result of decreased dopamine concentrations in the caudate and putamen from the degeneration of dopamine neurons in the SNpc that project to these brain regions (Figure 1). The early clinical symptoms of PD subjects are markedly alleviated by l-dopa therapy. The loss of dopamine neuron markers in the brain of persons with PD can be visualized and quantitatively measured using state-of-theart neuroimaging techniques such as PET and SPECT. 


\section{Idiopathic PD and Mn-Induced Parkinsonism: The Early Writings of James Parkinson and John Couper}

In 1817, the physician James Parkinson published the first description of a neurological disorder that is now recognized by his name, Parkinson's disease (Parkinson 1817). His monograph, titled An Essay on the Shaking Palsy, describes five cases with shaking palsy, a term that was vaguely employed by medical writers at the time. He commented that

[T] he first symptoms perceived are, a slight sense of weakness, with a proneness to trembling in some particular part; sometimes in the head, but most commonly in one of the hands and arms. These symptoms gradually increase in the part first affected; and at an uncertain period, but seldom in less than twelve months or more, the morbid influence is felt in some other part. Thus assuming one of the hands and arms to be first attacked, the other, at this period becomes similarly affected.

Parkinson went on to say that as the disease proceeds, "walking becomes a task which cannot be performed without considerable attention." As the malady proceeds,

The propensity to lean forward becomes invincible, and the patient is thereby forced to step on the toes and fore part of the feet, whilst the upper part of the body is thrown so far forward as to render it difficult to avoid falling on the face... irresistibly impelled to take much quicker and shorter steps, and thereby to adopt unwillingly a running pace.

He then described the later stages,

As the disease proceeds toward its last stage, the trunk is almost permanently bowed, the muscular power is more decidedly diminished, and the tremulous agitation becomes violent. . His words are now scarcely intelligible,

and he is no longer able to feed himself. "The chin is now almost immoveably bent down upon the sternum" ... with the saliva continually trickling from the mouth. "The power of articulation is lost."

Twenty years after the essay by James Parkinson, John Couper described the first symptoms of Mn toxicity in humans (Couper 1837). The observations made in this brief essay are important in order to understand the working conditions and the symptoms of $\mathrm{Mn}$ intoxication in humans. A comparison of the two essays makes it clear how the two conditions are similar and how they are different. Couper wrote,

In the chemical works of Charles Tennant and Co., a considerable number of men are employed in grinding the black oxide of manganese, to be employed in the manufacture of bleaching powder. The surface of their bodies is of course constantly covered with the manganese; the air which they breathe is loaded with it in the form of fine powder, and they are ever exposed, from neglect of cleanliness, to swallow portions of it along with their food.

It is clear from this description that working conditions were very hazardous and personal hygiene was poor. As a result, these workers were exposed to extremely high concentrations of $\mathrm{Mn}$ on a daily basis.

In the description of the workers who were affected by Mn poisoning, Couper went on to say that,

The loss of power is most apparent in the lower extremities, which are so considerably affected that the patient staggers, and inclines to run forward when he attempts to walk. The arms are also weakened, but only to a small extent. The patient complains that in speaking he cannot make himself heard by persons at a moderate distance, as formerly; and the inability seems to depend, not on any defect of articulation, but on weakness of voice. There is no deficiency of sensibility in any part of the body; the intellect and external senses are unimpaired; but there is an obvious expression of vacancy in the countenance, apparently from the paralyzed state of the muscles of the face. From the same cause the saliva is apt to escape from the mouth, especially during speaking. There is no tremor in any part of the body.

A comparison of the two essays indicates that certain symptoms are similar and some are different from those in PD. The Mn-exposed workers exhibited gait disturbance, a propensity to fall, masked face, hypophonia and dysphonia, and drooling. The absence of resting tremor, a prominent and early cardinal sign of PD patients, as initially described by James Parkinson, is a distinguishing observation that is different from PD in these workers heavily exposed to Mn.

Since the initial observations by Couper, other reports in the early 1900s noted the toxic effects of Mn from occupational exposures but, compared with PD, the number of studies is rather limited. The description of these subsequent $\mathrm{Mn}$ cases supported the initial observations by Couper but also added additional symptoms such as micrographia, dystonia (cock gait), and action and postural tremor (Table 1; for reference to these early cases, see Lee 2000; Perl and Olanow 2007). Table 1 outlines the motor symptoms from the literature related to occupational Mn exposures and other human conditions in 
Table 1. Clinical symptoms of parkinsonism in idiopathic PD and in human conditions with elevated brain Mn concentrations.

\begin{tabular}{|c|c|c|c|c|c|c|c|c|}
\hline Reference & Category & $\begin{array}{l}\text { Resting } \\
\text { tremor }\end{array}$ & $\begin{array}{l}\text { Action/ } \\
\text { postural } \\
\text { tremor }\end{array}$ & Bradykinesia & Rigidity & $\begin{array}{l}\text { Postu } \\
\text { instab }\end{array}$ & $\begin{array}{l}\text { ural } \\
\text { ility }\end{array}$ & $\begin{array}{c}\text { Gait } \\
\text { disorder }\end{array}$ \\
\hline Jankovic 2008 & IPD & + & & + & + & + & & + \\
\hline Lee 2000 & $\mathrm{Mn}-\mathrm{O}$ & & + & + & + & + & & + \\
\hline Yamada et al. 1986 & $\mathrm{Mn}-\mathrm{O}$ & & & + & + & + & & + \\
\hline Cook et al. 1974 & $\mathrm{Mn}-\mathrm{O}$ & & + & + & & + & & + \\
\hline Mena et al. 1967 & $\mathrm{Mn}-\mathrm{O}$ & & + & + & + & + & & + \\
\hline Huang 2007 (summary of Taiwan cohort) & $\mathrm{Mn}-\mathrm{O}$ & - & + & + & + & + & & + \\
\hline Kessler et al. 2003 & $\mathrm{Mn}-\mathrm{O}$ & + & + & + & + & + & & + \\
\hline Kenangil et al. 2006 & Welding & & & + & + & + & & + \\
\hline Bowler et al. 2006 & Welding & & + & + & + & & & + \\
\hline Josephs et al. 2005 & Welding & - & + & + & & + & & + \\
\hline Racette et al. 2001 & Welding & + & & + & + & + & & \\
\hline Sadek et al. 2003 & Welding & & + & & + & + & & + \\
\hline Meral et al. 2007 & Ephedron & Some & + & + & + & + & & + \\
\hline Sikk et al. 2007 & Ephedron & & & & & + & & + \\
\hline de Bie et al. 2007 & Ephedron & & & + & + & + & & + \\
\hline Sanotsky et al. 2007 & Ephedron & & & + & + & + & & + \\
\hline Varlibas et al. 2009 & Ephedron & & + & + & & + & & \\
\hline Stepens et al. 2008 & Ephedron & - & & + & + & + & & + \\
\hline Selikhova et al. 2008 & Ephedron & & & + & & + & & + \\
\hline Colosimo and Guidi 2009 & Ephedron & & + & + & + & + & & \\
\hline Nagatomo et al. 1999 & PN & Some & & & + & & & + \\
\hline Burkhard et al. 2003 & LD & - & + & + & + & + & & + \\
\hline Klos et al. 2006 & LD & - & + & + & + & & & + \\
\hline Klos et al. 2005 & LD & & + & + & + & + & & + \\
\hline Faviani et al. 2007 & LD & & + & + & + & + & & + \\
\hline Kim et al. 2007 & LD & & + & + & + & + & & + \\
\hline Schaumberg et al. 2006 & $\mathrm{Mn}-\mathrm{O} / \mathrm{LD}$ & - & + & - & - & + & & + \\
\hline Reference & Dystonia $\mathrm{M}$ & Micrographia & $\begin{array}{r}\text { Difficulty } \\
\text { backn } \\
\text { turning, }\end{array}$ & $\begin{array}{ll}\text { walking } & \text { Hyp } \\
\text { ward, } & \text { dys } \\
\text { pull-test } & \text { dys }\end{array}$ & $\begin{array}{l}\text { ophonia, } \\
\text { phonia/ } \\
\text { sarthria }\end{array}$ & Falls & & $\begin{array}{l}\text { l-Dopa } \\
\text { esponse }\end{array}$ \\
\hline Jankovic 2008 & + Secondary & + & + & + & + & & & xcellent \\
\hline Lee 2000 & & + & + & + & + & + & & \\
\hline Yamada et al. 1986 & + & & & & & & & \\
\hline Cook et al. 1974 & & + & + & + & + & & & Minimal \\
\hline Mena et al. 1967 & + & + & + & + & + & & & \\
\hline Huang 2007 (summary of Taiwan cohort) & + & + & + & + & + & & Minim & mal to none \\
\hline Kessler et al. 2003 & & & + & + & + & + & & None \\
\hline Kenangil et al. 2006 & + & & & & & + & & None \\
\hline Bowler et al. 2006 & + & & & & & & & None \\
\hline Josephs et al. 2005 & & & + & + & + & & & Minimal \\
\hline Racette et al. 2001 & & & & & & & & xcellent \\
\hline Sadek et al. 2003 & + & & & & & + & & None \\
\hline Meral et al. 2007 & + & & + & + & + & & & None \\
\hline Sikk et al. 2007 & + & & + & + & + & & & \\
\hline de Bie et al. 2007 & & + & + & + & + & & & None \\
\hline Sanotsky et al. 2007 & + & + & + & + & + & + & & None \\
\hline Varlibas et al. 2009 & + & & + & + & & & Minim & mal to none \\
\hline Stepens et al. 2008 & + & + & + & + & + & + & & None \\
\hline Selikhova et al. 2008 & + & + & + & + & + & & & None \\
\hline Colosimo and Guidi 2009 & + & & + & + & + & + & & None \\
\hline Nagatomo et al. 1999 & + & & + & + & + & + & & \\
\hline Burkhard et al. 2003 & + & & + & + & + & + & & Minimal \\
\hline Klos et al. 2006 & & & & & & & & None \\
\hline Klos et al. 2005 & & & & & & & & Minimal \\
\hline Faviani et al. 2007 & & + & & & + & + & & Partial \\
\hline Kim et al. 2007 & & & + & + & & & & None \\
\hline Schaumberg et al. 2006 & + & & & & + & & & ot tested \\
\hline
\end{tabular}

Abbreviations: IPD, idiopathic PD; LD, liver disease; Mn-O, occupational Mn exposure; PN, parenteral nutrition; secondary, later in time; some, minimal; + , the symptom was present; -, the symptom was not present; blank spaces, neither was indicated. 
which Mn levels are markedly increased in the brain, and the motor symptoms in idiopathic PD. The conclusion from these reports is that, although several of the clinical signs between PD and $\mathrm{Mn}$-induced parkinsonism are similar, in $\mathrm{Mn}$-induced parkinsonism, unlike in PD, there is an absence of resting tremor and the lack of a response to 1-dopa. Also, the progression of Mninduced parkinsonism appears to be a gait disorder of early onset with dystonia that occurs much later in the slow progression of the movement abnormalities in PD.

\section{Mn-Induced Parkinsonism from Human Conditions Not Related to Occupational Exposures}

Besides occupational exposures, other conditions have been shown to increase accumulation of Mn in the brain and have been valuable sources of information in understanding Mn-induced neurological dysfunction, including parkinsonism.

Psychostimulant drug abusers: ephedron. Recently, there have been a number of reports, primarily originating from Eastern European countries and Russia, of young addicts afflicted with an atypical form of parkinsonism (de Bie et al. 2007; Meral et al. 2007; Sanotsky et al. 2007; Selikhova et al. 2008; Sikk et al. 2007; Stepens et al. 2008; Varlibas et al. 2009) (Table 1). This form of parkinsonism is the result of intravenous injections of a psychostimulant drug called "ephedrone" or "Russian cocktail," a drug in which ephedrine is oxidized using potassium permanganate and acetic acid (Sanotsky et al. 2007; Stepens et al. 2008). Typically, this homemade chemical mixture is not purified before intravenous injection, so milligram to gram amounts of $\mathrm{Mn}$ are injected with multiple injections occurring during the course of weeks and months. Normal Mn concentrations in whole blood are d" 10-12 ig/L, but the blood $\mathrm{Mn}$ concentrations in these young addicts have been measured at levels as high as 2,000-3,000 ìg/L (Stepens et al. 2008; Varlibas et al. 2009). Consistent with the fact that high concentrations of $\mathrm{Mn}$ are injected, most of these individuals exhibit bilateral T1-weighted magnetic resonance imaging (MRI) hyperintensive signals in the basal ganglia and other brain regions reflecting Mn accumulation (Figure 1, Table 2).

The parkinsonian signs in these young drugabuse subjects are consistent with those in occupationally exposed Mn workers (Table 1). An important observation on the etiological role of $\mathrm{Mn}$ in the parkinsonism in these young addicts is based on the fact that movement abnormalities are observed in ephedrone users in Eastern Europe and Russia where the chemical preparation uses potassium permanganate as the oxidizing agent. However, a parkinsonian syndrome has not been observed in North America, where chro-
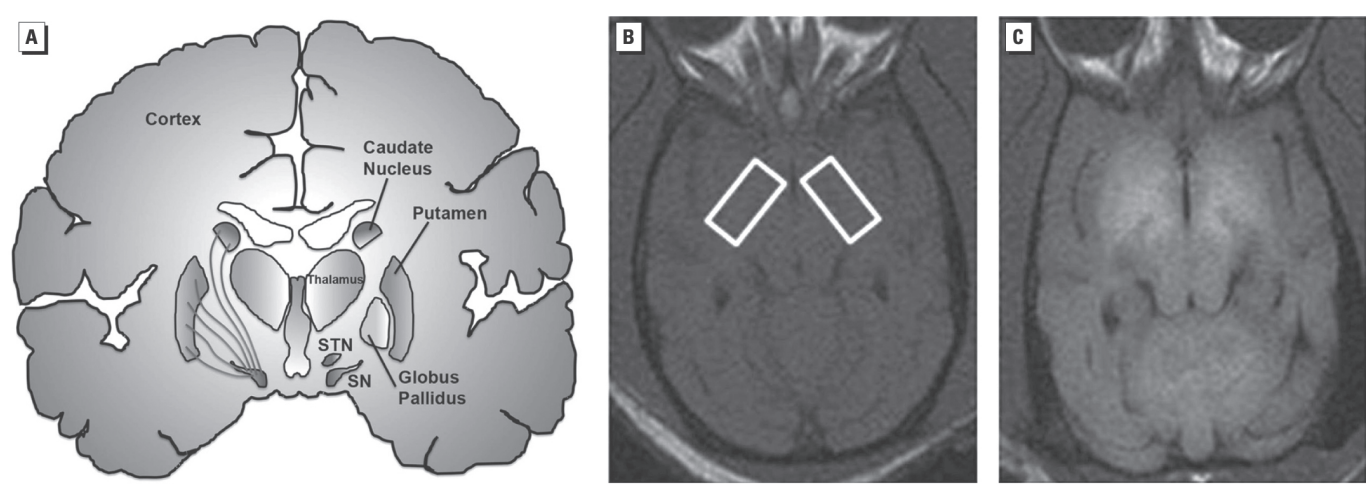

Figure 1. (A) Schematic depicting the different brain structures comprising the basal ganglia (labeled in the right hemisphere). The left hemisphere shows the nigrostriatal dopamine fibers whose cell bodies are located in the substantia nigra (SN) and innervate the caudate and putamen. These are the axonal projections that degenerate in Parksinson's disease. T1-weighted MRI at the level of the globus pallidus of a control nonhuman primate brain (B; boxed areas) and a nonhuman primate brain exposed to $\mathrm{Mn}(\mathrm{C})$. Note the increase in signal intensity (white areas) in the Mn-exposed animal (C) relative to the control animal (B). SNT, subthalamic nucleus. 
mate is used as the oxidizing agent rather than potassium permanganate (Selikhova et al. 2008; Stepens et al. 2008). The most parsimonious explanation is that $\mathrm{Mn}$ is the causative agent in this atypical form of parkinsonism.
Patients with liver disease. There is evidence of parkinsonism associated with chronic liver disease. Patients with advanced cirrhosis have been documented with a form of parkinsonism with clinical symptoms similar to $\mathrm{Mn}$-induced parkin-

Table 2. Brain imaging studies in idiopathic PD and in human conditions that show elevated concentrations of $\mathrm{Mn}$ in the brain.

\begin{tabular}{|c|c|c|c|c|}
\hline Reference & Category & T1-MRI & PET/SPECT & Blood or tissue Mn \\
\hline Felicio et al. 2009 & IPD & NTD & $\begin{array}{l}{\left[{ }^{18} \mathrm{~F}\right] \text {-fluoro-dopa }} \\
\text { PETDAT/SPECT/ } \\
\text { PETVMAT2/PET } \\
\text { (all significantly } \\
\text { decreased) }\end{array}$ & NTD \\
\hline Brooks et al. 1992 & IPD & NTD & $\begin{array}{l}\mathrm{D} 2 \mathrm{R} / \mathrm{PET} \\
\text { (increased or } \\
\text { normal) }\end{array}$ & NTD \\
\hline Leenders 2003 & IPD & NTD & $\begin{array}{l}\mathrm{D} 2 \mathrm{R} / \mathrm{PET} \\
\text { (increased or } \\
\text { normal) }\end{array}$ & NTD \\
\hline Huang 2007 (summary of Taiwan cohort) & $\mathrm{Mn}-0$ & $\uparrow$ & $\begin{array}{l}{\left[{ }^{18} \mathrm{~F}\right] \text {-fluoro-dopa }} \\
\text { PET } \\
\text { (normal)DAT/ } \\
\text { SPECT } \\
\text { (normal)D2R/ } \\
\text { PET (small } \\
\text { decrease) }\end{array}$ & $\uparrow$ \\
\hline Kim et al. 2002 & $\mathrm{Mn}-0$ & $\uparrow$ & $\begin{array}{l}\text { DAT/SPECT } \\
\text { (decreased) }\end{array}$ & $\uparrow$ \\
\hline Bowler et al. 2006 & Welding & $\uparrow$ & $\mathrm{NP}$ & $\uparrow$ \\
\hline Josephs et al. 2005 & Welding & $\uparrow$ & $\mathrm{NP}$ & $\uparrow$ \\
\hline Racette et al. 2001 & Welding & No signal & $\begin{array}{l}{\left[{ }^{18} \mathrm{~F}\right] \text {-fluoro-dopa }} \\
\text { PET (major } \\
\text { reduction) }\end{array}$ & NP \\
\hline Sadek et al. 2003 & Welding & $\uparrow$ & $\mathrm{NP}$ & $\uparrow$ \\
\hline Meral et al. 2007 & Ephedron & $\uparrow$ & $\mathrm{NP}$ & NP \\
\hline de Bie et al. 2007 & Ephedron & $\uparrow$ & $\begin{array}{l}{\left[{ }^{18} \mathrm{~F}\right] \text {-fluoro-dopa }} \\
\text { PET (minor } \\
\text { reduction) }\end{array}$ & $\uparrow$ \\
\hline Sanotsky et al. 2007 & Ephedron & $\uparrow$ & $\mathrm{NP}$ & $\mathrm{NP}$ \\
\hline Varlibas et al. 2009 & Ephedron & $\uparrow$ & $\mathrm{NP}$ & $\uparrow$ \\
\hline Stepens et al. 2008 & Ephedron & $\uparrow$ & NP & $\uparrow$ \\
\hline Selikhova et al. 2008 & Ephedron & $\uparrow$ & $\begin{array}{l}\text { DAT/SPECT } \\
\text { (normal) }\end{array}$ & $\uparrow$ \\
\hline Colosimo and Guidi 2009 & Ephedron & Normal & $\begin{array}{l}\mathrm{DAT} / \mathrm{PET} \\
\text { (normal) }\end{array}$ & NP \\
\hline Racette et al. 2005 & LD & $\uparrow$ & $\begin{array}{l}{\left[{ }^{18} \mathrm{~F}\right] \text {-fluoro-dopa }} \\
\text { PET (major } \\
\text { reduction) }\end{array}$ & $\uparrow$ \\
\hline Bukhard et al. 2003 & LD & $\uparrow$ & NP & $\uparrow$ \\
\hline Klos et al. 2006 & LD & $\uparrow$ & NP & $\uparrow$ \\
\hline Klos et al. 2005 & LD & $\uparrow$ & NP & $\uparrow$ \\
\hline Faviani et al. 2007 & LD & $\uparrow$ & NP & $\uparrow$ \\
\hline Kim et al. 2007 & LD & $\uparrow$ & $\begin{array}{l}\text { DAT/SPECT } \\
\text { (normal) }\end{array}$ & $\uparrow$ \\
\hline Schaumberg et al. 2006 & $\mathrm{Mn}-\mathrm{O} / \mathrm{LD}$ & $\uparrow$ & NP & $\uparrow$ \\
\hline Kessler et al. 2003 & Mn-O & NP & $\begin{array}{l}\mathrm{D} 2 \mathrm{R} / \mathrm{PET} \\
\text { (decreased) }\end{array}$ & NP \\
\hline
\end{tabular}

Abbreviations: IPD, idiopathic PD; LD, liver disease; Mn-O, occupational Mn exposure; NP, not performed; NTD, not typically done. PET/SPECT studies were done in the striatum (caudate and putamen). Arrows indicate increased T1-weighted MRI signal in the globus pallidus and other basal ganglia structures. 
sonism. This finding is likely because $\mathrm{Mn}$ is excreted in the bile, and in persons with chronic liver disease, the excretion of $\mathrm{Mn}$ is markedly impaired, with subsequent accumulation in the brain. The clinical symptoms associated with idiopathic PD, chronic liver disease, ephedrone abuse, and occupational exposures to $\mathrm{Mn}$ are described in Table 1. Some of the symptoms are common to those in PD, but there are significant differences. In conditions in which $\mathrm{Mn}$ is the most likely etiological agent for the parkinsonism, there is a rapid progression of the motor symptoms and early gait and postural impairment with focal dystonia (cock gait in worst cases). Further, there is an absence of resting tremor but an expression of action or postural tremor and no consistent asymmetry (Table 1). Elevated concentrations of Mn in basal ganglia structures have been measured in liver disease patients (Klos et al. 2006) and are consistent with basal ganglia hyperintensive signals in T1-weighted MRI. Increased T1-weighted MRI hyperintensive signal is not observed in PD patients. From a clinical perspective, most persons who were occupationally exposed to $\mathrm{Mn}$, users of ephedron, and patients with liver disease and parkinsonism are not responsive or are minimally responsive to l-dopa therapy, the mainstay therapy that ameliorates the early movement abnormalities in PD (Table 1). Racette et al. (2001) noted an exception to this general observation; they found that welders with movement abnormalities (presumably from the Mn in the welding fume) had an excellent response to 1-dopa therapy. However, a positive response to l-dopa therapy is not typical of Mn-induced parkinsonism but is representative of PD (Table 1). Further, their study has been criticized by several investigators (Ravina et al. 2001; Sadak and Schulz 2001).

\section{Neuroimaging Studies in Idiopathic PD and Mn-Induced Parkinsonism}

With the advent of molecular imaging techniques in the 1980s, a number of neuroimaging modalities have been used to understand the structural, cellular, and molecular changes that occur in neurological and neurodegenerative diseases. In PD and conditions associated with $\mathrm{Mn}$-induced parkinsonism, three principal neuroimaging modalities have been used: T1-weighted MRI, SPECT, and PET. Structural MRI and magnetic resonance spectroscopy have also been used, but to a lesser extent, and are not discussed in this review.

In human conditions where $\mathrm{Mn}$ is the most likely etiological agent for the parkinsonism, a high percentage of the subjects exhibited a hyperintensive signal in T1-weighted MRI that is typically first observed in the globus pallidus and in other basal ganglia structures such as the substantia nigra, caudate, and putamen (Figure 1, Table 2). This finding is because $\mathrm{Mn}$ is a paramagnetic metal that decreases the relaxation time in a T1-weighted MRI, which makes the signal hyperintensive. It should be noted that the basal ganglia T1-weighted MRI was normal in a small number of persons who had been occupationally exposed to Mn, who had injected the ephedron preparation, or patients who had liver disease. This obsesrvation is most likely due to the fact that the T1-weighted MRI study was performed after a significant amount of time had passed from the time of exposure to the point when the Mn had been eliminated from the brain. Importantly, for patients with liver disease, the hyperintensive T1-weighted MRI signal in the basal ganglia is normalized after liver transplantation (Aggarwal et al. 2006) that corrects the impairment in Mn excretion.

SPECT and PET studies have been used to assess nigrostriatal dopamine neuron terminal markers both in PD and in Mn-induced parkinsonism (Table 2). In PD patients, SPECT and PET studies have shown a progressive loss of DAT and MAT2 and reduced dopa decarboxylase activity using [18F]-fluoro-dopa PET (Table 2). Importantly, $\mathrm{PD}$ patients have normal or increased levels of D2R in the striatum (Table 2). A much more limited number of SPECT or PET studies are available for conditions associated with Mn-induced parkinsonism. The most extensive series of PET and SPECT human studies that examined presynaptic and postsynaptic dopamine terminal markers was performed over several years in four workers who had been occupationally exposed to $\mathrm{Mn}$ in Taiwan. These workers exhibited movement abnormalities that were consistent with Mn-induced parkinsonism, and the findings from several clinical and neuroimaging studies have been recently summarized by Huang (2007). In general, these occupationally exposed workers with Mn-induced movement abnormalities had normal [18F]-fluoro-dopa PET, normal DAT SPECT, and a small decrease in D2R PET. A decrease in D2R levels measured by PET also has been noted in another case report (Kessler et al. 2003) (Table 2). The findings summarized by Huang (2007) are consistent with a normal synthesis of dopamine and normal levels of DAT, both of which are significantly decreased in PD patients (Table 2). Further, in Mn- 
induced parkinsonism, Huang (2007) observed small but significantly decreased D2R signals, which is the opposite of what is observed in PD. These findings have provided evidence for a lack of nigrostriatal dopamine neuron degeneration in workers occupationally exposed to $\mathrm{Mn}$ who exhibit parkinsonism.

For the most part, available evidence from SPECT and PET studies of dopamine neuron terminal markers in ephedron addicts and in liver disease patients have confirmed the lack of an effect of elevated brain Mn on dopa decarboxylase activity using [18F]-1-dopa PET and on DAT levels in the striatum (Colosimo and Guidi 2009; de Bie et al. 2007; Kim et al. 2007; Selikhova et al. 2008; see Table 2). In one study, Kim et al. (2002) observed significant reductions in DAT levels measured by SPECT in two workers who had been occupationally exposed to Mn (Table 2). However, both subjects exhibited an excellent response to l-dopa therapy, which is typically not observed in Mn-induced parkinsonism (Table 1). Therefore, the possibility that these two subjects were PD cases with concurrent $\mathrm{Mn}$ exposure is high. Also, scientists generally assumed that decreased levels of DAT as measured by PET or SPECT are representative of dopamine terminal loss in the striatum. Although this is clearly the case in PD patients where the neuropathology is well documented, this cannot be assumed in Mnexposed subjects because studies have shown that Mn directly interacts with DAT. Chen et al. (2006) have shown that an acute dose of Mn produces a transient increase in DAT levels in the nonhuman primate striatum. This transient increase is most likely due to acute inhibition of DAT, which produces an up-regulation of the protein. Consistent with this hypothesis, a direct inhibitory effect of $\mathrm{Mn}$ on radioligand binding to DAT was demonstrated in the same study. That is, Mn inhibited [3H]-WIN 35,428 binding to DAT in neuronal membranes from rat striatum. Thus, in the study by Kim et al. (2002) and in other SPECT and PET DAT imaging studies, it is possible that the decrease in DAT measured by SPECT may not be representative of DAT loss in the striatum (or, by inference, of dopamine terminal degeneration); rather, the decrease in DAT may reflect the ability of Mn to interfere with radioligand binding to DAT. For both of the Mn-exposed cases in the Kim et al. (2002) study, there had been a long history of Mn exposure. Thus, it is possible that a progressive accumulation of Mn occurred in the striatum that reached concentrations sufficient to interfere with radioligand binding to DAT.
This possibility can be explored in future studies because other dopamine terminal markers such as VMAT2 can be imaged and are less likely to be influenced by elevated levels of Mn in the striatum. In two studies, Racette et al. described reduced [18F]-fluoro-dopa PET signals in two welders (2001) and in a patient with liver disease (2005). These findings suggest the possibility of nigrostriatal dopamine neuron degeneration. However, other factors need to be considered. First, in the 2001 study, 15 career welders were studied, and [18F]-fluoro-dopa PET was performed in only two of them. Second, all of the welders were responsive to l-dopa therapy, and this response is not consistent with $\mathrm{Mn}$-induced parkinsonism. Third, none of the welders tested with T1-weighted MRI scans (8 of 15) exhibited a hyperintensive signal in the basal ganglia despite being career welders. Further, one of the two welders that had reduced [18F]-fluoro-dopa uptake in the posterior putamen had a positive family history of PD, which suggests the possibility of a familial form of the disease. Taking all of the information together, the most parsimonious explanation is that the parkinsonism in these welders was not likely associated with the $\mathrm{Mn}$ in the welding fumes. The second study (Racette et al. 2005) was a case report of a patient with alcoholic cirrhosis. This single subject had parkinsonian symptoms and elevated $\mathrm{Mn}$ in the blood and was responsive to l-dopa therapy, a clinical response that has not been observed in Mn-induced parkinsonism. This case had a reduction in [18F]-fluoro-dopa uptake throughout the caudate and putamen; however, the caudate and posterior putamen ratio was more similar to the control subjects than to the PD controls. In summary, the evidence from neuroimaging studies have indicated that in different human conditions where $\mathrm{Mn}$ concentrations markedly increase in the brain to produce movement abnormalities, there is a lack of degeneration of the nigrostriatal dopaminergic terminals.

\section{Neurochemical and Neuropathological Studies in PD and Mn-Induced Parkinsonism}

As pointed out by Perl and Olanow (2007), a very limited number of autopsy studies have been performed on workers who were exposed to $\mathrm{Mn}$ or on persons with other related conditions in which Mn was increased in the brain (Table 3 ). Most of the neuropathological studies associat- 
ed with occupational Mn exposures were performed in the early 1900s and lacked detailed examination of brain tissue. Neurochemical methods used in the early studies did not have the sensitivity and specificity available today. Nevertheless, most studies described marked changes in the globus pallidus of Mn-exposed individuals, with no remarkable effects on pigmented cells of the substantia nigra, which indicates a lack of an effect on dopamine cell bodies, the only midbrain neurons that contain melanin (Table 3). Neurochemical studies of the brains of patients with liver disease have confirmed for the most part the results from neuroimaging studies: a significant decrease in D2R levels in the basal ganglia and no observed decrease in dopamine levels (Table 1). In one study, Mousseau et al. (1993) used in vitro autoradiography and found decreased D2R levels in the globus pallidus and putamen with no change in D1-dopamine receptors (D1Rs) in the basal ganglia of patients with liver disease (Table 3 ).

In general, the available neurochemical and neuropathological evidence from subjects with increased Mn concentrations in the brain suggests primary involvement of the globus pallidus, expressing the loss or shrinkage of neurons and glial cell activation. Consistent evidence has shown that D2R levels are decreased, and one study indicated no change in D1R. Most studies have indicated a lack of degeneration of midbrain dopamine neurons, which is consistent with the majority of the neuroimaging studies. Parenthetically, in the studies that indicated a loss or a shrinking of neurons in the globus pallidus or striatum of Mn-exposed subjects, no attempt has been made to identify the neuronal phenotype affected.

\section{Behavioral, Neuroimaging, Neurochemical, and Neuropathological Evidence of Mn Neurotoxicity in Nonhuman Primates}

Behavior. Experimental animals have been used to advance the understanding of Mn neurotoxicity. Rodent studies are not described in this review because, unlike nonhuman primates, they lack behavioral similarities to humans and are less sensitive to $\mathrm{Mn}$ than are humans and nonhuman primates. Nonhuman primates have improved our understanding of the effects of Mn on motor function, in vivo brain chemistry, and neuropathology (Table 4). Historically, nonhuman primate studies can be divided into two categories. The studies from the 1960s to the early 1990s used Mn doses that were considerably higher than those used in studies from 1995 to 2008 (Table 4). Most studies before 1995 used cumulative doses $>300 \mathrm{mg} \mathrm{Mn} / \mathrm{kg}$ body weight. These early studies did not use neuroimaging techniques because of their more recent availability, with the exception of Newland and Weiss (1992) (Table 4), who administered very low doses of Mn and used T1-weighted MRI. Another important difference between the early studies and more recent ones has been the use of quantitative, advanced histological, neurochemical, and neuropathological techniques to analyze brain tissue. For example, some of the early studies used gross anatomical examination of brain tissue, and the analysis of neurotransmitter levels used colorimetric reactions that were prone to interference and lacked sensitivity compared with current state-of-the-art techniques (Table 4).

Table 3. Neurochemical studies in human postmortem brain tissue.

\begin{tabular}{|c|c|c|}
\hline Reference & Category & Neurochemistry/neuropathology \\
\hline Bernheimer et al. 1973 & $\mathrm{Mn}-\mathrm{O}$ & $\begin{array}{l}\text { Putamen, pallidum, and red nucleus exhibited generalized } \\
\text { astroglial activationMild degree of pallidal atrophyDecreased DA } \\
\text { levels in caudate, putamen, and SNLewy bodies in SN }\end{array}$ \\
\hline Yamada et al. 1986 & $\mathrm{Mn}-\mathrm{O}$ & $\begin{array}{l}\text { Moderate decrease in the number of large nerve cells, and } \\
\text { shrinking of cellsPigmented cells of the SN were intact }\end{array}$ \\
\hline Perl and Olanow 2007 & $\mathrm{Mn}-\mathrm{O}$ & $\begin{array}{l}\text { Describes studies from the early } 1900 \text { s to } 2004 \text { indicating } \\
\text { pathological effects in GP with no remarkable effects in SN }\end{array}$ \\
\hline Butterworth et al. 1995 & Liver disease & Loss of $\mathrm{D} 2 \mathrm{R}$ in $\mathrm{GP}$ \\
\hline Mousseau et al. 1993 & Liver disease & $\begin{array}{l}{\left[{ }^{3} \mathrm{H}\right]-\mathrm{SCH} 23390 \text { autoradiography }(\mathrm{D} 1 \mathrm{R}) \text { unchanged in all basal }} \\
\text { ganglia regions tested }\left[{ }^{3} \mathrm{H}\right] \text {-Spiperone autoradiography }(\mathrm{D} 2 \mathrm{R}) \\
\text { decreased in GP and putamen; no change in caudate }\end{array}$ \\
\hline Bergeron et al. 1989 & Liver disease & DA/HPLC not changed in the caudate; HVA increased \\
\hline
\end{tabular}

Abbreviations: DA, dopamine; GP, globus pallidus; Mn-O, occupational Mn exposure; SN, substantia nigra. 
Table 4. Behavioral, neuroimaging, and neurochemical studies in Mn-exposed nonhuman primates.

\begin{tabular}{|c|c|c|c|c|c|c|}
\hline Reference & Species & Route & $\Sigma \mathrm{Mn}$ dose & Behavior & Neuroimaging & $\begin{array}{l}\text { Neuropathology/ } \\
\text { neurochemistry }\end{array}$ \\
\hline $\begin{array}{l}\text { Pentschew } \\
\text { et al. } 1963\end{array}$ & $\begin{array}{c}\text { Rhesus (5 } \\
\text { monkeys, only } 1 \\
\text { described) }\end{array}$ & im (Mn dioxide) & $\begin{array}{l}695 \mathrm{mg} \mathrm{Mn} / \mathrm{kg} \\
\text { (calculated) }\end{array}$ & $\begin{array}{c}\text { Excitability } \\
\text { Loss of postural } \\
\text { stability } \\
\text { Falling upon } \\
\text { jumping } \\
\text { Clumsiness } \\
\text { No cogwheel, } \\
\text { tremor, or } \\
\text { involuntary } \\
\text { movements }\end{array}$ & $\mathrm{ND}$ & $\begin{array}{l}\text { Neuronal loss and } \\
\text { gliosis in } \\
\text { subthalamic } \\
\text { nucleus and } \\
\text { medial segment of } \\
\text { GPGliosis in SN } \\
\text { (?)Atrophic nerve } \\
\text { cells in lateral } \\
\text { pallidum }\end{array}$ \\
\hline $\begin{array}{l}\text { Neff et al. } \\
1969\end{array}$ & $\begin{array}{l}\text { Squirrel monkey } \\
\text { (control = 4; } \\
\text { Mn-group A = } \\
\text { 5; Mn-group B } \\
=6)\end{array}$ & sc (Mn dioxide) & $\begin{array}{l}379 \mathrm{mg} \mathrm{Mn} / \mathrm{kg} \\
\text { in highest dose } \\
\text { group } \\
\text { (calculated) }\end{array}$ & $\begin{array}{l}\text { Muscular rigidity } \\
\text { Impaired } \\
\text { equilibrium } \\
\text { Tremors on } \\
\text { intension } \\
\text { Impaired } \\
\text { equilibrium }\end{array}$ & ND & $\begin{array}{l}\text { Decreased DA and } \\
\text { NE in caudate }\end{array}$ \\
\hline $\begin{array}{l}\text { Chandra et } \\
\text { al. } 1979\end{array}$ & Rhesus (4) & Oral & $\begin{array}{c}23,580 \mathrm{mg} \mathrm{Mn} / \\
\mathrm{kg}\left(\mathrm{MnCl}_{2}\right) \\
\text { (calculated) }\end{array}$ & ND & ND & $\begin{array}{l}\text { Decreased DA in } \\
\text { striatum and } \\
\text { midbrain }\end{array}$ \\
\hline $\begin{array}{l}\text { Bird et al. } \\
1984\end{array}$ & Rhesus (4) & $\begin{array}{l}\text { Inhalation ( } \mathrm{Mn} \\
\text { oxide) }\end{array}$ & $\begin{array}{c}30 \mathrm{mg} \mathrm{Mn} / \mathrm{m}^{3} \\
\text { air (exposure } \\
\text { rate) }\end{array}$ & $\begin{array}{c}\text { No behavioral or } \\
\text { neurological } \\
\text { abnormalities }\end{array}$ & ND & $\begin{array}{c}\text { Decreased DA in } \\
\text { caudate and GP } \\
\text { but not in } \\
\text { putamen or SN }\end{array}$ \\
\hline $\begin{array}{l}\text { Eriksson et } \\
\text { al. } 1987\end{array}$ & Rhesus (4) & sc (Mn oxide) & $\begin{array}{l}1,543 \mathrm{mg} \mathrm{Mn} / \mathrm{kg} \\
\quad \text { (calculated) }\end{array}$ & $\begin{array}{l}\text { Hyperactive } \\
\text { tending to fall } \\
\text { then hypoactive } \\
\text { Unsteady gait } \\
\text { Action tremor } \\
\text { Loss of power in } \\
\text { limbs } \\
\text { Clumsy hands } \\
\text { and feet } \\
\text { movement }\end{array}$ & $\mathrm{ND}$ & $\begin{array}{l}\text { Severe neuronal } \\
\text { loss and gliosis in } \\
\text { GP, rest of brain } \\
\text { appears normal } \\
\text { Decreased DA and } \\
\text { DOPAC in } \\
\text { putamen but not } \\
\text { changed in the } \\
\text { caudate } \\
\text { HVA levels normal } \\
\text { in most animals } \\
\text { Decreased dopa } \\
\text { decarboxylase } \\
\text { activity in } \\
\text { putamen of two- } \\
\text { thirds of the } \\
\text { animals } \\
\text { ChAT activity } \\
\text { reduced in GP of } \\
\text { all animals } \\
\text { GAD activity } \\
\text { unaffected } \\
\text { Glutathione levels } \\
\text { decreased in the } \\
\text { striatum, GP, and } \\
\text { SN of one third of } \\
\text { the animals }\end{array}$ \\
\hline $\begin{array}{l}\text { Newland et } \\
\text { al. } 1989\end{array}$ & $\begin{array}{l}\text { Long-tailed } \\
\text { macaque (3) }\end{array}$ & $\begin{array}{l}\text { iv and } \\
\text { inhalation } \\
\left(\mathrm{MnCl}_{2}\right)\end{array}$ & $\begin{array}{c}30-50 \mathrm{mg} \\
\mathrm{Mn} / \mathrm{kg} \\
\text { (injection) }\end{array}$ & ND & $\begin{array}{c}\uparrow \mathrm{T} 1-\mathrm{MRI} \\
\text { hyperintensity } \\
\text { basal ganglia }\end{array}$ & ND \\
\hline $\begin{array}{l}\text { Newland } \\
\text { and Weiss } \\
1992\end{array}$ & Cebus (3) & iv $\left(\mathrm{MnCl}_{2}\right)$ & $\begin{array}{l}40-60 \mathrm{mg} \\
\mathrm{Mn} / \mathrm{kg}\end{array}$ & Action tremor & $\begin{array}{c}\uparrow \mathrm{T} 1-\mathrm{MRI} \\
\text { hyperintensity } \\
\text { basal ganglia }\end{array}$ & ND \\
\hline
\end{tabular}


Table 4. continuation

\begin{tabular}{|c|c|c|c|c|c|c|}
\hline Reference & Species & Route & $\Sigma \mathrm{Mn}$ dose & Behavior & Neuroimaging & $\begin{array}{l}\text { Neuropathology/ } \\
\text { neurochemistry }\end{array}$ \\
\hline $\begin{array}{l}\text { Eriksson et } \\
\text { al. 1992a }\end{array}$ & $\begin{array}{l}\text { Long-tailed } \\
\text { macaque ( } 3 \text { ) }\end{array}$ & $\begin{array}{l}\text { sc }(\mathrm{Mn} \\
\text { oxide })\end{array}$ & $\begin{array}{c}\text { 333-444 mg } \\
\mathrm{Mn} / \mathrm{kg} \\
\text { (calculated) }\end{array}$ & $\begin{array}{c}\text { Decreased } \\
\text { activity in } 1 / 2 \text { of } \\
\text { the Mn-exposed } \\
\text { animals }\end{array}$ & ND & $\begin{array}{c}\text { DAT/autorad } \\
\text { (decreased in caudate } \\
\text { and putamen, no } \\
\text { change in GP) } \\
\text { D1R/autorad } \\
\text { (decreased in caudate } \\
\text { and putamen, no } \\
\text { change in GP) } \\
\text { D2R/autorad (no } \\
\text { change in any region) } \\
\text { mAChR/autorad (no } \\
\text { change in any region) } \\
\text { GABAaR/autorad (no } \\
\text { change in any region) }\end{array}$ \\
\hline $\begin{array}{l}\text { Eriksson et } \\
\text { al. } 1992 \text { b }\end{array}$ & $\begin{array}{l}\text { Long-tailed } \\
\text { macaque (2) }\end{array}$ & $\begin{array}{l}\text { sc }(\mathrm{Mn} \\
\text { oxide })\end{array}$ & $\begin{array}{l}680 \mathrm{mg} \mathrm{Mn} / \mathrm{kg} \\
\text { (calculated) }\end{array}$ & $\begin{array}{l}\text { Unsteady gait } \\
\text { Hypoactivity } \\
\text { Clumsiness of } \\
\text { hands and feet }\end{array}$ & $\begin{array}{c}\text { DAT/PET }(60 \% \\
\text { decrease) } \\
\text { D2R/PET (40\% } \\
\text { decrease then } \\
\text { normalized) } \\
\text { l-Dopa/PET } \\
\text { (normal) } \\
\uparrow \text { T1-MRI } \\
\text { hyperintensity in } \\
\text { basal ganglia }\end{array}$ & ND \\
\hline $\begin{array}{l}\text { Shinotoh et } \\
\text { al. } 1995\end{array}$ & Rhesus (3) & iv $(\mathrm{MnCl} 2)$ & $\begin{array}{c}71-87 \\
\mathrm{mg} \mathrm{Mn} / \mathrm{kg}\end{array}$ & $\begin{array}{l}\text { Two animals } \\
\text { hypoactive, one } \\
\text { normal } \\
\text { Not responsive } \\
\text { to l-dopa }\end{array}$ & $\begin{array}{c}\text { D2R/PET } \\
\text { 1-Dopa/PET } \\
\text { (normal) } \\
\text { FDG/PET (normal) } \\
\uparrow \text { T1-MRI } \\
\text { hyperintensity basal } \\
\text { ganglia }\end{array}$ & $\begin{array}{l}\text { Minimal cell loss and } \\
\text { prominent gliosis in } \\
\text { GP and lesser degree in } \\
\text { SNpr (normal) } \\
\text { SNpc relatively spared }\end{array}$ \\
\hline $\begin{array}{l}\text { Olanow et } \\
\text { al. } 1996\end{array}$ & $\begin{array}{l}\text { Rhesus (3) } \\
\quad \text { (same } \\
\text { animals as } \\
\text { Shinotoh et } \\
\text { al. 1995) }\end{array}$ & iv $(\mathrm{MnCl} 2)$ & $\begin{array}{c}71-87 \\
\mathrm{mg} \mathrm{Mn} / \mathrm{kg}\end{array}$ & $\begin{array}{l}\text { Two animals } \\
\text { hypoactive, one } \\
\text { normal } \\
\text { Not responsive } \\
\text { to l-dopa }\end{array}$ & $\begin{array}{l}\text { See Shinotoh et al. } \\
\text { (1995) }\end{array}$ & $\begin{array}{c}\text { Minimal cell loss and } \\
\text { prominent gliosis in } \\
\text { GP and to lesser degree } \\
\text { in SNprS } \\
\text { Npc appeared normal } \\
\text { Striatal DA and HVA } \\
\text { levels are normal in } \\
\text { two affected animals }\end{array}$ \\
\hline $\begin{array}{l}\text { Dorman et } \\
\text { al. } 2006\end{array}$ & Rhesus (20) & Inhalation & $\begin{array}{l}\text { Various levels } \\
\text { of exposure }\end{array}$ & ND & $\begin{array}{c}\uparrow \mathrm{T} 1-\mathrm{MRI} \\
\text { hyperintensity in } \\
\text { basal ganglia }\end{array}$ & $\mathrm{ND}$ \\
\hline $\begin{array}{l}\text { Chen et al. } \\
2006\end{array}$ & Baboon (2) & sc and iv & $\begin{array}{c}10-100 \mathrm{mg} \\
\mathrm{Mn} / \mathrm{kg} \text { (acute) }\end{array}$ & ND & $\begin{array}{c}\text { DAT/PET } \\
\text { (transient increase) }\end{array}$ & ND \\
\hline $\begin{array}{l}\text { Guilarte et } \\
\text { al. } 2006 \mathrm{a}\end{array}$ & $\begin{array}{l}\text { Cynomolgus } \\
(3-5)\end{array}$ & iv & $\begin{array}{l}165.5 \pm 4.7 \mathrm{mg} \\
\mathrm{Mn} / \mathrm{kg}(\text { range } \\
=152-174)\end{array}$ & $\begin{array}{l}\text { Subtle deficits in } \\
\text { fine motor } \\
\text { control } \\
\text { Small decrease } \\
\text { in activity }\end{array}$ & $\begin{array}{c}\text { DAR/PET } \\
\text { (significantly } \\
\text { decreased) } \\
\text { DAT/PET (normal) } \\
\text { D2R/PET (normal) }\end{array}$ & $\begin{array}{l}\text { DAT/autorad (normal) } \\
\text { D2R/autorad (normal) } \\
\text { TH/immuno } \\
\text { histochemistry } \\
\text { (normal) } \\
\text { DA-HVA/HPLC } \\
\text { (normal) }\end{array}$ \\
\hline $\begin{array}{l}\text { Guilarte et } \\
\text { al. } 2006 \mathrm{~b}\end{array}$ & $\begin{array}{c}\text { Cynomolgus } \\
(4)\end{array}$ & iv & $\begin{array}{l}165.5 \pm 4.7 \mathrm{mg} \\
\mathrm{Mn} / \mathrm{kg}(\text { range } \\
=152-174)\end{array}$ & $\begin{array}{l}\text { See Guilarte et } \\
\text { al. } 2006 \mathrm{a}\end{array}$ & $\begin{array}{c}\uparrow \mathrm{T} 1-\mathrm{MRI} \\
\text { hyperintensity in } \\
\text { basal ganglia and } \\
\text { other brain } \\
\text { regionsMRS } \\
\text { changes in regions } \\
\text { outside basal } \\
\text { ganglia }\end{array}$ & $\begin{array}{l}\text { See Guilarte et al. } \\
\qquad(2006 \mathrm{a})\end{array}$ \\
\hline
\end{tabular}


Table 4. continuation

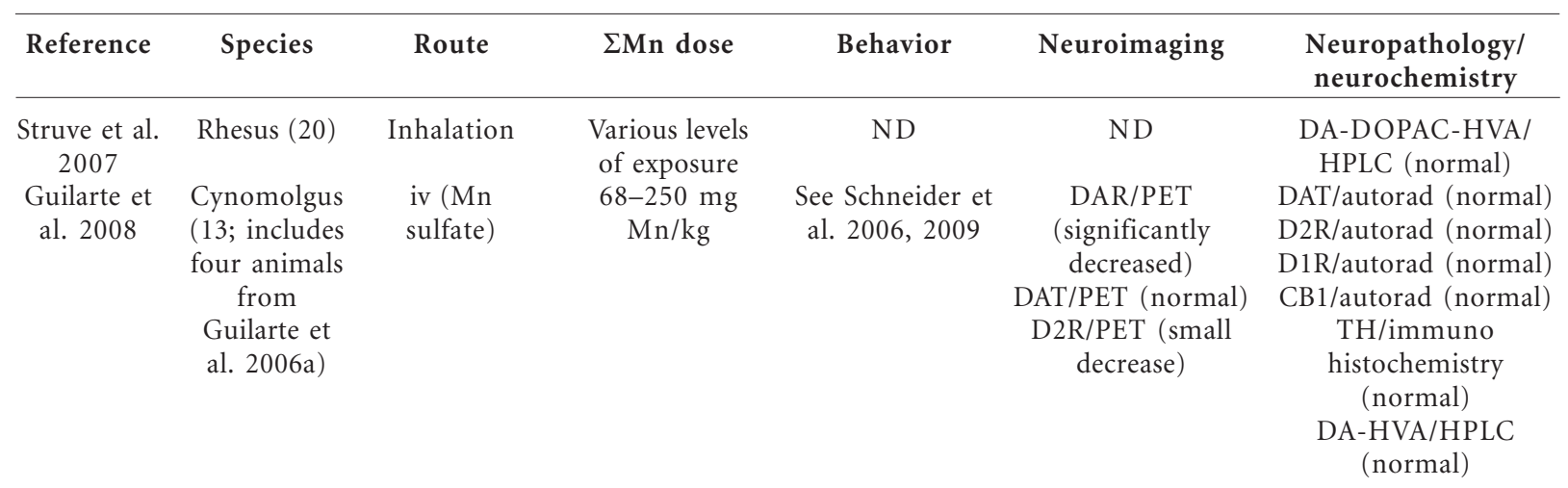

Abbreviations: autorad, autoradiography; CB1, cannabinoid receptor 1; ChAT, choline acetyltransferase; DA, dopamine; DAR, dopamine release; DOPAC, 3,4-dihydroxyphenylacetic acid; D2R, dopamine receptor; FDG, fluorodeoxyglucose; GABAaR, $\gamma$-aminobutyric acid A receptor; GAD, glutamic acid decarboxylase; GP, globus pallidus; im, intramuscular; iv, intravenous; mAChR, muscarinic acetylcholine receptor; MRS, magnetic resonance spectroscopy; ND, not determined; NE, norepinephrine; sc, subcutaneous; SN, substantia nigra; SNpr, substantia nigra pars reticulata; TH, tyrosine hydroxylase. Arrows indicate increased T1-weighted MRI signal in the globus pallidus and other basal ganglia structures.

From a behavioral perspective, early nonhuman primate studies examined the effects of $\mathrm{Mn}$ on movement and coordination. It is clear from these studies that nonhuman primates exhibited movement abnormalities similar to those in Mnexposed humans (compare Tables 1 and 4), including loss of postural stability, excitability, hypoactivity, falling, muscular rigidity, tremors of intension or action tremor, unsteady gait, loss of power in limbs, and clumsy foot movement (Table 4). From 1995, studies used cumulative Mn concentrations $<300 \mathrm{mg} \mathrm{Mn} / \mathrm{kg}$ body weight and found more subtle movement abnormalities, including hypoactivity, deficits in fine motor control, action tremor, and, more recently, deficits in working memory (Table 4). Consistent with the human literature, the Mn-induced motor abnormalities in nonhuman primates were not responsive to 1-dopa therapy (Shinotoh et al. 1995).

Neurochemistry. The early nonhuman primate studies of Mn exposure described decreased levels of dopamine in the caudate (Neff et al. 1969), striatum and midbrain (Chandra et al. 1979), caudate and globus pallidus but not in the putamen or substantia nigra (Bird et al. 1984), and putamen but no change in the caudate (Eriksson et al. 1987). Some relevant comments are important to put these results in perspective. First, in the study by Neff et al. (1969), the monkeys in group A were injected with single doses of 200 mg Mn oxide on two different occasions. The report indicated that " 2 weeks following the first injection, 1 control and $4 \mathrm{MnO} 2$ treated mon- keys died." This was a highly unusual event and makes one question the health status of these animals prior and during treatment. They reported a significant decrease of dopamine in the caudate of group A monkeys, and a less severe dopamine deficit but still a significant one in another group of Mn-exposed animals that received a third injection (group B).

In another study, Bird et al. (1984) exposed monkeys, via inhalation, to a $30 \mathrm{mg} / \mathrm{m} 3$ concentration of $\mathrm{Mn}$ for 5 days/week, $6 \mathrm{hr} /$ day, for 2 years. They found decreased levels of dopamine in the caudate and globus pallidus but not in the putamen and substantia nigra. Chandra et al. (1979) exposed male rhesus monkeys orally ( $\mathrm{MnCl} 2$ at $20 \mathrm{mg} / \mathrm{kg} /$ day) for 18 months and reported significant reductions in dopamine concentrations in the striatum $(-42 \%)$ and the midbrain $(-15 \%)$. In this study, two observations were important. First, the brain was dissected, and the different regions were frozen at $-20^{\circ} \mathrm{C}$. For dopamine analysis, this temperature is not the most appropriate for storing fresh tissue, because dopamine autooxidizes readily. Second, the dopamine recovery for the method used was less than desirable and ranged from $72-84 \%$. Although a comparison of control and treated dopamine tissue content is still possible, often in these early studies, the control and Mn-treated animals were euthanized at different times; thus potential differences in dopamine tissue content could result from differences in storage time and conditions. For example, in the study by Neff et al. (1969), 
Mn-exposed animals that received a higher cumulative Mn dose exhibited less dopamine loss than did animals with a lower dose whose tissues were stored for a longer time.

Eriksson et al. (1987) measured reduced concentrations of dopamine in the putamen and globus pallidus but not in the caudate, although one of the three animals analyzed did express a decrease in dopamine content in the caudate. An observation in the Eriksson et al. (1987) study that has relevance to a mechanism of action of $\mathrm{Mn}$ is that in the brains of these monkeys, in which they measured significant decrements in tissue dopamine concentration, they found no significant effect on glutathione concentrations in two of the three monkeys examined. In general, these early studies demonstrate differences in basal ganglia regions where dopamine concentrations appear to be decreased and the regional pattern does not follow the well-characterized loss of dopamine in idiopathic PD (Dauer and Przedborski 2003; Felicio et al. 2009).

The most consistent observation of these early studies was that Mn produced morphological changes in the globus pallidus, subthalamic nuclei, and substantia nigra pars reticulata, whereas the SNpc remained intact (Table 4). More recent studies (after 1995) that have used cumulative $\mathrm{Mn}$ doses < $300 \mathrm{mg} / \mathrm{kg}$ and state-of-the-art high-performance liquid chromatography (HPLC) with electrochemical detection analytical methods have provided no evidence of changes in dopamine concentrations in the caudate and putamen (Guilarte et al. 2006a, 2008; Olanow et al. 1996; Struve et al. 2007) (Table 4).

In vitro autoradiography. In vitro quantitative receptor autoradiography has been used to examine dopamine neuron markers in the brain of Mn-exposed nonhuman primates (Table 4). The groups headed by Eriksson in Sweden (1992a) and by Guilarte in the United States (2006a, 2008), have used this approach extensively because not only is it quantitative, it also offers exquisite anatomical information with high resolution. Eriksson et al. (1992a) performed receptor autoradiography studies in the basal ganglia of monkeys exposed to $0.1 \mathrm{~g} \mathrm{Mn} /$ month for 26 months. They indicated that this dosing regimen was comparable with what workers might inhale in dusty environments. They found that the binding of $[3 \mathrm{H}]$-mazindol to DAT (the presumed target, but see below) was reduced by $75 \%$ in the caudate and putamen of Mn-exposed animals. However, there were technical problems that need to be discussed: a) The authors stated that the level of nonspecific $[3 \mathrm{H}]$-mazindol binding in the caudate and putamen was $50 \%$ and $60 \%$, respectively. This level of nonspecific binding was very high, so the specific binding signalto-noise (nonspecific binding) ratio was very low. Typically in this type of assay, one wants a low level of nonspecific binding, in the range of 10$15 \%$ of total binding. b) [3H]-Mazindol is known to bind to other monoaminergic uptake sites besides DAT (May et al. 1994). To ensure that one is selectively measuring DAT, an antagonist for the other monoaminergic uptake sites should be included in the assay. This procedure was not performed by Eriksson et al. (1992a); thus, the effect of $\mathrm{Mn}$ on the $[3 \mathrm{H}]$-mazindol autoradiography results were a combination of DAT and other monoaminergic uptake sites. c) As pointed out, even if $[3 \mathrm{H}]$-mazindol was made selective for DAT by including antagonists for other monoaminergic transporters, a reduction in $[3 \mathrm{H}]$-mazindol binding to DAT would not necessarily reflect dopamine terminal loss, but it could represent a competitive inhibition of $\mathrm{Mn}$ with radioligand binding to DAT as shown by Chen et al. (2006). Parenthetically, Eriksson et al. (1992a) also found a significant decrease in [3H]-SCH 23390 binding to D1R in the caudate and putamen with no change in $[3 \mathrm{H}]$-spiperone binding to $\mathrm{D} 2 \mathrm{R}$ in the same regions. These results were opposite to what Eriksson et al. (1992b) and Guilarte et al. (2008) reported with in vivo PET imaging and in vitro autoradiography - that is, decreased D2R and no effect on D1R.

Guilarte et al. (2006a, 2008) have examined the largest cohort of Mn-exposed nonhuman primates using in vivo and in vitro methods (see Table 4). In a preliminary report in which four Mn-exposed animal were used, they found no significant effect of Mn exposure (mean cumulative Mn dose, $165.5 \mathrm{mg} \mathrm{Mn} / \mathrm{kg}$ body weight; range, 152-174 mg Mn/kg body weight) on DAT or D2R receptor levels using autoradiography or tyrosine hydroxylase immunohistochemistry, or on the concentration of dopamine and its metabolite homovanillic acid (HVA) measured by HPLC with electrochemical detection in the caudate or putamen, relative to naive controls (Guilarte et al. 2006a). These findings clearly indicated the lack of an effect of this cumulative Mn dose on the nigrostriatal dopaminergic system (but see "Neuroimaging studies," below). In a subsequent publication with a larger number of Mn-exposed animals, Guilarte et al. (2008) essentially found the same results. Further, Mn exposure had no effect on $\mathrm{D} 1 \mathrm{R}$ or cannabinoid receptor 1 levels in the 
basal ganglia. This latter study not only included a naive control group in which the animals did not receive $\mathrm{Mn}$ or neuroimaging studies, but it also included an imaged control group in which the neuroimaging studies were done without $\mathrm{Mn}$ exposure. The inclusion of an imaged control group was essential because one of the longitudinal PET studies included the administration of amphetamine (Guilarte et al. 2006a, 2008), a psychostimulant that depletes dopamine levels and down-regulates DAT. This control group provided valuable information for assessing the effect of amphetamine alone. Although several of the dopamine neuron markers that were analyzed postmortem, such as dopamine and DOPAC $(3,4-$ dihydroxyphenylacetic acid) in the putamen, DAT and VMAT2 in the caudate and putamen and D2R in the putamen were significantly lower in Mnexposed animals than in naive controls; they were not different from all controls when the imaged control group was included. The values for these parameters in the imaged control animals were actually lower than those for the Mn-exposed animals. The fact that studies of Mn-exposed animals that received amphetamine with PET had higher levels of these dopamine markers than did imaged controls that received the same amphetamine with PET but no Mn suggests that Mn has an "antagonistic effect" on the action of amphetamine on these dopaminergic markers. Because this action on dopaminergic markers is mediated by DAT, these results provide evidence that $\mathrm{Mn}$ interacts directly with DAT and are consistent with other studies that indicate an interaction of $\mathrm{Mn}$ with DAT (Anderson et al. 2007; Chen et al. 2006; Ingersoll et al. 1999).

Neuroimaging studies: MRI and PET. Similar to the studies involving humans exposed to $\mathrm{Mn}$, several investigators have performed neuroimaging studies of nonhuman primates to examine the distribution of $\mathrm{Mn}$ in the brain by T1weighted MRI and brain chemistry changes using PET. The T1-weighted MRI studies (Newland et al. 1989; Newland and Weiss 1992) (Table 4) showed that Mn first accumulates in the globus pallidus and produces a hyperintensive signal in T1-weighted MRI even at relatively low doses of Mn. Thus, it is a sensitive method for detecting small increases in brain Mn concentrations. These findings have been confirmed by other investigators, and subsequent studies have shown that although the basal ganglia is one of the first to accumulate $\mathrm{Mn}$, other brain structures also accumulate the metal, albeit to a lesser extent (Dorman et al. 2006; Ingersoll et al. 2006b).
PET imaging in nonhuman primates exposed to Mn was first performed by Eriksson (1992b) (Table 4). They studied two monkeys exposed to $\mathrm{Mn}$ for 16 months that received [11C]nomifensine PET to measure DAT (although this ligand also recognizes other monoaminergic transporters), [11C]-raclopride PET for D2R, and [11C]-1-dopa for 1-dopa decarboxylase activity. They found a progressive decrease in [11C]nomifensine binding as a function of cumulative dose in both animals. One of the animals had a transient decrease in [11C]-raclopride binding to $\mathrm{D} 2 \mathrm{R}$ that returned to baseline by the end of the exposure period, and no effect of Mn treatment on [11C]-1-dopa PET was observed. These studies indicate that dopamine neurons are not degenerating, but there is a potential loss of dopamine terminals based on the [11C]-nomifensine PET. However, a firm conclusion that chronic Mn results in the loss of DAT and presumably dopamine neuron terminals in the striatum cannot be made because [11C]-nomifensine is not a selective DAT ligand and because Mn can directly inhibit ligand binding to DAT.

Shinotoh et al. (1995) performed PET studies in three monkeys (not all monkeys received the three different types of PET studies) that were chronically treated with $\mathrm{Mn}$. These investigators found no significant effect of Mn on [18F]-fluoro-l-dopa PET, [11C]-raclopride PET, or [18F]deoxyglucose PET despite the fact that the animals exhibited hypoactivity (Table 4). Thus, their work is also consistent with the lack of degeneration of nigrostriatal dopaminergic neurons.

Neuroimaging studies: new PET findings. Since the study by Shinotoh et al. (1995), there has been a lack of neuroimaging studies to examine the effects of chronic Mn exposure on brain chemistry in nonhuman primates. Guilarte et al. (2006a, 2006b, 2008) have recently undertaken a large multidisciplinary effort to more broadly examine the longitudinal effects of chronic Mn exposure on behavior, in vivo brain chemistry, and brain pathology in the same animals (only the PET studies related to the dopaminergic system were described here). They performed PET studies of presynaptic and postsynaptic "structural proteins” such as DAT ([11C]-methylphenidate as the PET radioligand) and D2R ([11C]-raclopride as the PET radioligand) to examine various markers of the dopaminergic synapse. A PET study to assess dopaminergic function was also included. Although [18F]-fluoro-dopa PET is a perfectly valid and useful functional marker of dopaminergic activity, this method interrogates 
the ability of dopamine neurons to synthesize dopamine, and it may indirectly measure the dopamine-releasing capacity of dopamine neurons. Guilarte et al. (2006a, 2008) used a more direct method to assess in vivo dopamine release using a bolus plus continuous infusion of [11C]raclopride (D2R ligand) with amphetamine challenge (Zhou et al. 2006). This type of PET study is based on the ability of endogenous dopamine (released by the administration of amphetamine) to compete with the binding of [11C]-raclopride to D2R (Laruelle 2000). An animal with a high capacity to release dopamine will produce a large decrease in the amount of [11C]-raclopride uptake in the striatum, whereas an animal with a low capacity will produce a smaller change or no change. These studies showed that the most significant effect of chronic $\mathrm{Mn}$ at all of the cumulative doses of $\mathrm{Mn}$ administered was a marked inhibition ( $>50 \%$ on average) of in vivo dopamine release in the striatum measured by PET (Guilarte et al. 2006a, 2008) (Table 4). The effect of Mn on in vivo dopamine release was observed in the absence of a change in DAT levels and with a small but significant decrease on D2R levels in the striatum (Guilarte et al. 2008). Therefore, consistent with human and other nonhuman primate studies, this work also showed a lack of dopamine neuron degeneration. However, these studies provided new information: although chronic Mn exposure did not result in dopamine neuron degeneration, dopamine neurons were dysfunctional because they had a reduced capacity to release dopamine. Neurochemical studies in the brain of the same animals that received PET studies showed that the marked effect of Mn on in vivo dopamine release measured by PET was not due to a reduction in tissue dopamine levels, because dopamine concentrations were not significantly different from all controls (Guilarte et al. 2006a, 2008). It appears that the deficit of in vivo dopamine release is associated with the ability of Mn to disrupt presynaptic release mechanisms.

\section{Conclusions}

The available evidence from human and nonhuman primate studies using behavioral, neuroimaging, neurochemical, and neuropathological end points provides strong support to the hypothe- sis that, although excess levels of Mn accumulation in the brain results in an atypical form of parkinsonism, this clinical outcome is not associated with the degeneration of nigrostriatal dopaminergic neurons as is the case in PD. In fact, the new evidence suggests that it may be the dysfunction of this system or the inability to release dopamine that produces the movement abnormalities documented in Mn-exposed subjects. This new finding is consistent with the fact that 1-dopa therapy does not provide a benefit to the Mn-induced movement abnormalities as it does in PD (Lu et al. 1994) (Table 1). This is because Mn-induced motor dysfunction does not seem to be a problem of decreased synthesis or concentration of dopamine in presynaptic terminals, but rather a problem of the ability to release the available dopamine. These findings provide a starting point and a new avenue of research to delineate a putative mechanism of Mninduced movement abnormalities.

Although the latest research clearly suggests that the effects of Mn on presynaptic aspects of the dopaminergic synapse need further exploration, delineating its effects on postsynaptic proteins of the dopaminergic synapse or other neuronal systems downstream and on the role of glial cells is essential in order to achieve a greater understanding of the neurotoxicity of Mn. The continued use of neuroimaging techniques that have already been used to study Mn neurotoxicity, as well as some others such as diffusion tensor imaging, are also likely to provide new information. Ultimately, the most significant studies in understanding $\mathrm{Mn}$-induced parkinsonism are those in humans. From this perspective, persons who inject high doses of $\mathrm{Mn}$ in the ephedron preparations and workers who are occupationally exposed to moderate levels of $\mathrm{Mn}$ are cohorts in which comprehensive neurological assessments along with neuroimaging studies can provide longitudinal information about Mn neurotoxicity, its reversibility, and the usefulness of therapeutic strategies. Finally, although the preponderance of the behavioral, neuroimaging, and neuropathological evidence indicates that chronic Mn exposure does not cause degeneration of nigrostriatal dopamine neurons and PD, the parkinsonism and other neurological effects resulting from chronic Mn exposure are highly debilitating, and it should not be treated with any less importance. 


\section{References}

Aggarwal A, Vaidya S, Shah S, Singh J, Desai S, Bhatt M. 2006. Reversible parkinsonism and T1W pallidal hyperintensities in acute liver failure. Mov Disord 21:1986-1990.

Anderson JG, Cooney PT, Erikson KM. 2007. Inhibition of DAT function attenuates manganese accumulation in the globus pallidus. Environ Toxicol Pharmacol 23:179-184.

Antonini A, Schwarz J, Oertel WH, Beer HF, Madeja UD, Leenders KL. 1994. [11C]-raclopride and positron emission tomography in previously untreated patients with Parkinson's disease: influence of L-dopa and lisuride therapy on striatal dopamine D2 receptors. Neurology 44:1325-1329.

Bergeron M, Reader TA, Layrargues GP, Butterworth RF. 1989. Monoamines and metabolites in autopsied brain tissue from cirrhotic patients with hepatic encephalopathy. Neurochem Res 14:853-859.

Bernheimer H, Birkmayer W, Hornykiewicz O, Jellinger K, Seitelberger F. 1973. Brain dopamine and the syndromes of Parkinson and Huntington. Clinical, morphological and neurochemical correlations. $J$ Neurol Sci. 20:415-455.

Bird ED, Anton AH, Bullock B. 1984. The effect of manganese inhalation on basal ganglia dopamine concentrations in rhesus monkey. Neurotoxicology 5:5965.

Bowler RM, Koller W, Schulz PE. 2006. Parkinsonism due to manganism in a welder: neurological and neuropsychological sequelae. Neurotoxicology 27:327-332.

Brooks DJ, Ibanez V, Sawle GV, Playford ED, Quinn N, Mathias CJ, et al. 1992. Striatal D2 receptor status in patients with Parkinson's disease, striatonigral degeneration, and progressive supranuclear palsy measured with 11C-raclopride and positron emission tomography. Ann Neurol 31:184-192.

Burkhard PR, Delavelle J, Du Pasquier R, Spahr L. 2003. Chronic parkinsonism associated with cirrhosis: a distinct subset of acquired hepatocerebral degeneration. Arch Neurol 60:521-528.

Butterworth RF, Spahr L, Fontaine S, Layrargues GP. 1995. Manganese toxicity, dopaminerigc dysfunction and hepatic encephalopathy. Metab Brain Dis 10:259-267.

Chandra SV, Srivastava RS, Shukla GS. 1979. Regional distribution of metals and biogenic amines in the brain of monkeys exposed to manganese. Toxicol Lett 4:189-192.

Chen MK, Kuwabara H, Zhou Y, Adams RJ, Brasic JR, McGlothan JL, et al. 2008. VMAT2 and dopamine neuron loss in a primate model of Parkinson's disease. J Neurochem 105:78-90.

Chen MK, Lee JS, McGlothan JL, Furukawa E, Adams RJ, Alexander M, et al. 2006. Acute manganese administration alters dopamine transporter levels in the nonhuman primate striatum. Neurotoxicology 27:229-236.

Colosimo C, Guidi M. 2009. Parkinsonism due to ephedrone neurotoxicity: a case report. Eur J Neurol 16:e114-e115.

Cook DG, Fahn S, Brait KA. 1974. Chronic manganese intoxication. Arch Neurol 30:59-64.
Couper J. 1837. On the effects of black oxide of manganese when inhaled in the lungs. Br Ann Med Pharmacol 1:41-42.

Dauer W, Przedborski S. 2003. Parkinson's disease: mechanisms and models. Neuron 39:889-909.

de Bie RM, Gladstone RM, Strafella AP, Ko JH, Lang AE. 2007. Manganese-induced Parkinsonism associated with methcathinone (Ephedrone) abuse. Arch Neurol 64:886-889.

Dorman DC, Struve MF, Wong BA, Dye JA, Robertson ID. 2006. Correlation of brain magnetic resonance imaging changes with pallidal manganese concentrations in rhesus monkeys following subchronic manganese inhalation. Toxicol Sci 92:219-227.

Ehringer H, Hornykiewicz O. 1960. Verteilung von Noradrenalin und Dopamin (3-hydroxytyramin) im Gehirn des Menschen und ihr Verhalten bei Erkrankungen des extrapyramidalem Systems [in German]. Klin Wochenschr 38:1236-1239.

Eriksson H, Gillberg PG, Aquilonius SM, Hedstrom KG, Heilbronn E. 1992a. Receptor alterations in manganese intoxicated monkeys. Arch Toxicol 66:359-364.

Eriksson H, Mägiste K, Plantin LO, Fonnum F, Hedström KG, Theodorsson-Norheim E, et al. 1987. Effects of manganese oxide on monkeys as revealed by a combined neurochemical, histological and neurophysiological evaluation. Arch Toxicol 61:46-52.

Eriksson H, Tedfoff J, Thuomas KA, Aquilonius SM, Hartvig P, Fasth KJ, et al. 1992b. Manganese induced brain lesions in Macaca fascicularis as revealed by positron emission tomography and magnetic resonance imaging. Arch Toxicol 66:403-407.

Faviani G, Rogacheski E, Wiederkehr JC, Khouri J, Cianfarano A. 2007. Liver transplantation in a patient with rapid onset parkinsonism-dementia complex induced by manganism secondary to liver failure. Arq Neuropsiquiatr 65:685-688.

Felicio AC, Shih MC, Godeiro-Junior C, Andrade LA, Bressan RA, Ferraz HB. 2009. Molecular imaging studies in Parkinson disease: reducing diagnostic uncertainly. Neurologist 15:6-16.

Gelb DJ, Oliver E, Gilamn S. 1999. Diagnosis criteria for Parkinson disease. Arch Neurol 56:33-39.

Guilarte TR, Burton NC, McGlothan JL, Verina T, Zhou Y, Alexander M, et al. 2008. Impairment of nigrostriatal dopamine neurotransmission by manganese is mediated by pre-synaptic mechanism(s): implications to manganese-induced parkinsonism. J Neurochem 107:1236-1247.

Guilarte TR, Chen MK, McGlothan JL, Verina T, Wong DF, Zhou Y, et al. 2006a. Nigrostriatal dopamine system dysfunction and subtle motor deficits in manganese-exposed nonhuman primates. Exp Neurol 202:381-390.

Guilarte TR, McGlothan JL, Degaonkar M, Chen MK, Barker PB, Syversen T, et al. 2006b. Evidence for cortical dysfunction and widespread manganese accumulation in the nonhuman primate brain following chronic manganese exposure: a $1 \mathrm{H}-\mathrm{MRS}$ and MRI study. Toxicol Sci 94:351-358.

Hornykiewicz O. 2006. The discovery of dopamine deficiency in the parkinsonian brain. J Neural Transm (suppl):9-15. 
Huang CC. 2007. Parkinsonism induced by chronic manganese intoxication-an experience in Taiwan. Chang Gung Med J 30:385-395.

Hughes AJ, Daniel SE, Ben Shlomo Y, Lees AJ. 2002. The accuracy of diagnosis of parkinsonian syndromes in a specialist movement disorder service. Brain 125:861-870.

Hughes AJ, Daniel SE, Lees AJ. 1993. The clinical features of Parkinson's disease in 100 histological proven cases. Adv Neurol 60:595-599.

Ingersoll RT, Montgomery EB Jr, Aposhian HV. 1999. Central nervous system toxicity of manganese. II: cocaine or reserpine inhibit manganese concentration in the rat brain. Neurotoxicology 20:467-476.

Jankovic J. 2008. Parkinson's disease: clinical features and diagnosis. J Neurol Neurosurg Psychiatry 79:368-376.

Josephs KA, Ahlskog JE, Klos KJ, Kumar N, Fealey RD, Trenerry MR, et al. 2005. Neurologic manifestations in welders with pallidal MRI T1 hyperintensity. Neurology 64:2033-2039.

Kenangil G, Ertan S, Sayilir I, Ozekmekçi S. 2006. Progressive motor syndrome in a welder with pallidal T1 hyperintensity on MRI: a two year follow-up. Mov Disord 21:2197-2200.

Kessler KR, Wunderlich G, Hefter H, Seitz RJ. 2003. Secondary progressive chronic manganism associated with markedly decreased striatal D2 receptor density. Mov Disord 18:217-218.

Kim J, Kim J-M, Kim YK, Shin JW, Choi SH, Kim SE, et al. 2007. Dopamine transporter SPECT of a liver cirrhotic with atypical parkinsonism. Ind Health 45:497-500.

Kim Y, Kim JM, Kim JW, Yoo CI, Lee CR, Lee JH, et al. 2002. Dopamine transporter density is decreased in parkinsonian patients with a history of manganese exposure: what does it mean? Mov Disord 17:568575.

Klos KJ, Ahlskog JE, Josephs KA, Fealey RD, Cowl CT, Kumar N. 2005. Neurologic spectrum of chronic liver failure and basal ganglia T1 hyperintensity on magnetic resonance imaging: probable manganese neurotoxicity. Arch Neurol 62:1385-1390.

Klos KJ, Ahlskog JE, Kumar N, Cambern S, Butz J, Burritt $\mathrm{M}$, et al. 2006. Brain metal concentrations in chronic liver failure patients with pallidal T1 MRI hyperintensity. Neurology 67:1984-1989.

Laruelle M. 2000. Imaging synaptic neurotransmission with in vivo binding competition techniques: a critical review. J Cereb Blood Flow Metab 20:423-451.

Lee JW. 2000. Manganese intoxication. Arch Neurol 57:597-599.

Lees AJ, Hardy J, Revesz T. 2009. Parkinson's disease. Lancet 373:2055-2066.

Leenders KL. 2003. Significance of nonpresynaptic SPECT tracer methods in Parkinson's disease. Mov Disord 18(suppl 7):S39-S42.

Louis ED, Klatka LA, Liu Y, Fahn S. 1997. Comparison of extrapyramidal features in 31 pathologically confirmed cases of diffuse Lewy body disease and 34 pathologically confirmed cases of Parkinson's disease. Neurology 48:376-380.
Lu CS, Huang CC, Chu NS, Calne DB. 1994. Levodopa failure in chronic manganism. Neurology 44:16001602.

May CH, Guilarte TR, Wagner HN Jr, Vogel S. 1994. Intrastriatal infusion of lisuride-a potential treatment for Parkinson's disease? Behavioral and autoradiographic studies in 6-OHDA lesioned rats. $\mathrm{Neu}$ rodegeneration 3:305-313.

Mena I, Marin O, Fuenzalida S, Cotzias GC. 1967. Chronic manganese poisoning. Clinical picture and manganese turnover. Neurology 17:128-136.

Meral H, Kutukcu Y, Atmaca B, Ozer F, Hamamcioglu K. 2007. Parkinsonism caused by chronic usage of intravenous potassium permanganate. Neurologist 13:92-94.

Mousseau DD, Perney P, Layrargues P, Butterworth RF. 1993. Selective loss of pallidal dopamine D2 receptor density in hepatic encephalopathy. Neurosci Lett 162:192-196.

Nagatomo S, Umehara F, Hanada K, Nobuhara Y, Takenaga S, Arimura K, et al. 1999. Manganese intoxication during total parenteral nutrition: report of two cases and review of the literature. J Neurol Sci 162:102-105.

Neff NH, Barrett RE, Costa E. 1969. Selective depletion of caudate nucleus dopamine and serotonin during chronic manganese dioxide administration to squirrel monkeys. Experientia 25:1140-1141.

Newland MC, Ceckler TL, Kordower JH, Weiss B. 1989. Visualizing manganese in the primate basal ganglia with magnetic resonance imaging. Exp Neurol 106:251-258.

Newland MC, Weiss B. 1992. Persistent effects of manganese on effortful responding and their relationship to manganese accumulation in the primate globus pallidus. Toxicol Appl Pharmacol 113:87-97.

Olanow CW, Good PF, Shinotoh H, Hewitt KA, Vingerhoets F, Snow BJ, et al. 1996. Manganese intoxication in the rhesus monkey: a clinical, imaging, pathologic, and biochemical study. Neurology 46:492498.

Parkinson J. 1817. An Essay on the Shaking Palsy. Available: http://www.gutenberg.org/files/23777/23777-h/ 23777-h.htm [accessed 3 June 2010].

Pentschew A, Ebner FF, Kovatch RM. 1963. Experimental manganese encephalopathy in monkeys. A preliminary report. J Neuropathol Exp Neurol 22:488499.

Perl DP, Olanow CW. 2007. The neuropathology of manganese-induced Parkinsonism. J Neuropathol Exp Neurol 66:675-682.

Racette BA, Antenor JA, McGee-Minnich L, Moerlein SM, Videen TO, Kotagal V, et al. 2005. [18F]FDOPA PET and clinical features in parkinsonism due to manganism. Mov Disord 20:492-496.

Racette BA, McGee-Minnich L, Moerlein SM, Mink JW, Videen TO, Perlmutter JS. 2001. Welding related parkinsonism: clinical features, treatment, and pathophysiology. Neurology 56:8-13.

Rajput AH, Rozdilsky B, Ang L. 1991. Occurrence of resting tremor in Parkinson's disease. Neurology 41:1298-1299. 
Ravina B, Siderowf A, Farrar J, Hurtig H. 2001. Welding-related parkinsonism: clinical features, treatment, and pathophysiology. Neurology 57:936-937.

Rinne UK, Laithinen A, Rinne JO, Nágren K, Bergman J, Ruotsalainen U. 1990. Positron emission tomography demonstrates dopamine D2 receptor supersensitivity in the striatum of patients with early Parkinson's disease. Mov Disord 5:55-59.

Sadak AH, Schulz PE. 2001. Welding-related parkinsonism: clinical features, treatment, and pathophysiology. Neurology 57:1738-1739.

Sadek AH, Rauch R, Schulz PE. 2003. Parkinsonism due to manganism in a welder. Int J Toxicol 22:393-401.

Sanotsky Y, Lesyk R, Fedoryshyn L, Komnatska I, Matviyenko Y, Fahn S. 2007. Manganic encephalopathy due to "ephedrone" abuse. Mov Disord 22:13371343.

Savitt JM, Dawson VL, Dawson TM. 2006. Diagnosis and treatment of Parkinson disease: molecules to medicine. J Clin Invest 116:1744-1754.

Schaumberg HH, Herskovitz S, Cassano VA. 2006. Occupational manganese neurotoxicity provoked by hepatitis C. Neurology 67:322-323.

Schneider JS, Decamp E, Clark K, Bouquio C, Syversen T, Guilarte TR. 2009. Effects of chronic manganese exposure on working memory in nonhuman primates. Brain Res 1258:86-95.

Schneider JS, Decamp E, Koser AJ, Fritz S, Gonczi H, Syversen T, et al. 2006. Effects of chronic manganese exposure on cognitive and motor functioning in nonhuman primates. Brain Res 1118:222-231.

Selikhova M, Fedoryshyn L, Matviyenko Y, Komnatska I, Kyrylchuk M, Krolicki L, et al. 2008. Parkinsonism and dystonia caused by illicit use of ephedrone-a longitudinal study. Mov Disord 23:2224-2231.

Shinotoh H, Snow BF, Hewitt KA, Pate BD, Doudet D, Nugent R, et al. 1995. MRI and PET studies of manganese-intoxicated monkeys. Neurology 45:11991204.

Sikk K, Taba P, Haldre S, Bergquist J, Nyholm D, Zjablov $G$, et al. 2007. Irreversible motor impairment in young addicts-ephedrone, manganism or both? Acta Neurol Scand 115:385-389.
Stepens A, Logina I, Liguts V, Aldins P, Eksteina I, Platkäjis A, et al. 2008. A Parkinsonian syndrome in methcathinone users and the role of manganese. $N$ Engl J Med 358:1009-1017.

Struve MF, McManus BE, Wong BA, Dorman DC. 2007. Basal ganglia neurotransmitter concentrations in rhesus monkeys following subchronic manganese sulfate inhalation. Am J Ind Med 50:772-778.

Tolosa E, Wenning G, Poewe W. 2006. The diagnosis of Parkinson's disease. Lancet Neurol 5:75-86.

Varlibas F, Delipoyraz I, Yuksel G, Filiz G, Tireli H, Gecim NO. 2009. Neurotoxicity following chronic intravenous use of "Russian cocktail." Clin Toxicol (Phila) 47:157-160

Vingerhoets FJ, Schulzer M, Calne DB, Snow BJ. 1997. Which clinical sign of Parkinson's disease best reflects the nigrostriatal lesion? Ann Neurol 41:58-64.

Wakabayashi K, Tanji K, Mori F, Takahashi H. 2007. The Lewy body in Parkinson's disease: molecules implicated in the formation and degradation of alpha-synuclein aggregates. Neuropathology 27:494506.

Yamada M, Ohno S, Okayasu I, Okeda R, Hatakeyama S, Watanabe H, et al. 1986. Chronic manganese poisoning: a neuropathological study with determination of manganese distribution in the brain. Acta Neuropathol 70:273-278.

Zhou Y, Chen M-K, Endres CJ, Ye W, Brasic JR, Alexander $\mathrm{M}$, et al. 2006. An extended simplified reference tissue model for the quantification of dynamic PET with amphetamine challenge. Neuroimage 33:550-563.

Received 30 November 2009 Accepted 19 April 2010 